\title{
ECOS DA MIGRAÇÃO - A QUESTÃO DA REPRESENTAÇÃO DO MIGRANTE EM ROMANCES DA LITERATURA BRASILEIRA CONTEMPORÂNEA
}

\author{
María del Pilar Tobar Acosta ${ }^{1}$

\section{Resumo}

No presente trabalho nos propusemos estudar a obra literária Inferno provisório volume 1: Mamma, son tanto felice, de Luiz Ruffato, observando a forma como o autor tratou a temática da imigração e de que forma compôs seu texto para representar a identidade dos imigrantes e de seus descendentes. Ao passo que procuramos entender as técnicas de construção e as estruturas usadas que permitem classificar a obra no contexto da produção contemporânea. Para tanto, usamos o referencial teórico dos estudos em pósmodernidade das ciências sociais, bem como o da crítica literária. Assim, para entender a estrutura da obra, em um primeiro momento, propusemos a ideia de "romance líquido" (baseada no conceito de modernidade líquida [BAUMAN, 2001]). E num segundo momento, abordamos o texto da obra propriamente dito, analisando cada uma das seis "histórias" (RUFFATO, 2005: p. 171) que compõem o que entendemos como a macro-história do livro, destacando os trechos nos quais aparecem referências aos imigrantes. Destarte, observamos que diferentemente das narrativas tradicionais sobre a vida de imigrantes, as quais constroem, para estes, uma identidade próxima à de herois conquistadores, a obra em questão retrata outra visão, muito mais crua e dessacralizada, sobre a imigração. O imigrante de Ruffato é um ser, que expulso por motivos econômicos de seu lugar de origem, parte em busca da promessa de "fazer a América" (FAUSTO, 1999) e acaba encalhando em uma realidade de nunca conseguir chegar, de nunca pertencer a lugar nenhum, e assim de repetir os mesmos passos nômades sempre procurando algo melhor.

Palavras chave: Narrativas Ficcionais sobre Imigração, Literatura Brasileira Contemporânea, Luiz Ruffato, Mamma, Son Tanto Felice.

A obra Inferno provisório volume 1: Mamma, son tanto felice, de Luiz Ruffato, é o livro inaugural de uma série projetada para ser composta por cinco volumes, dos quais quatro já foram publicados - Mamma, son tanto felice e $O$ mundo inimigo em 2005, Vista parcial da noite em 2006 e O livro das impossibilidades em 2008. Nessa

\footnotetext{
${ }^{1}$ María del Pilar Tobar Acosta é aluna de graduação do curso de Bacharelado em Letras da Universidade de Brasília e formada como Técnica em Música pelo Centro de Educação Profissional Escola de Música de Brasília. acosta.pilar@gmail.com
} 
série o autor retrata a saga da imigração italiana para o Brasil por meio de histórias de trabalhadores imigrantes italianos e de seus descendentes radicados na Zona da Mata de Minas Gerais, a partir da segunda metade do século XX em diante. O autor mostra como essas vidas se desenrolaram a partir de uma matriz rural patriarcal que veio com os italianos que aqui chegaram, e as questões que advieram do choque cultural e do desenraizamento por que essas pessoas tiveram de passar. A saga se dá, em um primeiro momento, em um contexto rural (Cidade de Rodeiro) e, posteriormente, em um contexto urbano (Cataguases, Ubá, São Paulo), e então se somam às questões supracitadas todos os antagonismos e problemáticas que o êxodo rural e a modernização forçada acarretaram a essas vidas.

O trabalho realizado teve como objetivo verificar de que maneira a obra foi estruturada, analisando as técnicas de construção usadas pelo autor, bem como localizar os trechos nos quais há referência à imigração ou aos imigrantes propriamente ditos, e, assim, verificar de que modo se construiu sua representação.

A primeira coisa que salta aos olhos ao se ler Mamma, son tanto felice é a sua estrutura, o que nos coloca frente à questão de classificação da obra. Como registrado por sua editora, a Record ${ }^{2}$, a obra seria um romance. Entretanto, o termo 'romance', em sua acepção mais geral, se refere a um gênero discursivo ${ }^{3}$ já consagrado pelo uso ao longo da história da literatura ocidental que apresenta características um tanto cristalizadas. Deste modo, definir a obra em questão como romance, como pertencente a esse gênero discursivo, gera uma expectativa de que esta obra seja, ao menos, no seu formato semelhante com obras que partilham essa mesma classificação. Todavia, o livro de que tratamos aqui se apresenta de uma forma bastante diferente da que se espera de uma obra dita romance, no que concerne a uma linearidade estrutural e narrativa. A obra de Ruffato divide-se em seis pedaços/trechos delimitados por títulos, sendo que alguns desses trechos apresentam também epígrafes. Mas, diferentemente do que esperaria um leitor tradicional, esses trechos mostram, quanto à questão formal, ritmos narrativos totalmente diferentes, estruturas internas particulares, entre outras características específicas de cada um deles. E quanto à questão temática, entre um trecho e outro e até em um mesmo trecho, existem também diferenças - contextos, momentos, personagens - porém, há manutenção da coesão do texto do livro por conta de índices - referência a uma mesma cidade, citação de um mesmo sobrenome que poderia ser entendido como ligação de parentesco entre diferentes personagens, aparição de um mesmo personagem em trechos diferentes, citação a um mesmo santo de devoção ou a um mesmo hábito alimentar, entre outros - que caracterizam que ainda se estaria falando da mesma realidade projetada, sem para tanto se tratar de um continuo linear como se esperaria de um romance tradicionalmente entendido.

Outra questão particular desta obra é que ela mantém um diálogo muito forte com outras obras artísticas. O que se nota pelas várias epígrafes, bem como, pelo fato de que em diversos momentos do livro, é possível reconhecer formas de contar e traços herdados de outros romances, tradicionalmente entendidos, de outras obras literárias

\footnotetext{
2 “Mamma, son tanto felice (Inferno Provisório - Volume I romance, 2005)" in http://www.record.com.br/autor_sobre.asp?id_autor=275, consultado em 27/03/09, às 14 h43. 3 “(...) tipos relativamente estáveis de enunciados, sendo isso que denominamos gêneros do discurso." (BAKHTIN, 1992: p. 279)
} 
pertencentes a outros gêneros discursivos - poema, conto, novela, fábula, entre outros e também traços estilísticos de gêneros de outras artes, como por exemplo, do cinema ou da música (como veremos mais adiante).

Retomando as divisões da obra, esbarramos, mais uma vez, com a questão terminológica, pois, dizer que seriam contos, capítulos, ou mesmo fragmentos seria reduzir o que realmente representam dentro do contexto dessa produção artística de Ruffato. Quando lemos o sumário percebemos que o mesmo autor nos dá a pista do que seriam esses trechos, ele propõe: "As histórias:", intituladas "Uma fábula", "Sulfato de morfina", "Aquário", "A expiação", "O Alemão e a puria" e "O segredo". Seriam, então, seis histórias compondo uma mesma macro-história encerrada na brochura que une essas páginas. Sendo esse livro - essas seis histórias encadeadas e unidas - por sua vez, um pedaço, um fragmento, de cinco volumes. Como veremos, o final do livro como um todo, bem como de suas sucessivas histórias, não leva a um ponto de exaustão ou acabamento ${ }^{4}$, a partir do qual seria possível processar uma ressignificação de tudo o que foi dito anteriormente e passar para um segundo momento enunciativo (a compreensão e formação de uma atitude responsiva por parte do leitor), como também esperaríamos de um romance tradicional.

Com isso, acaba sendo difícil reduzir essa obra à clássica terminologia "romance". Vemos que Ruffato propõe uma nova ideia de romance, sendo que essa proposta não está solta no tempo e no espaço, pelo contrário, ela vem construída sobre um diálogo com tudo o que veio antes dela e paralelamente a ela (BAKHTIN, 1992). O autor se apropria de um gênero discursivo literário e constrói o que propomos, a partir de agora, chamar de "romance líquido", ou romance da modernidade líquida. Nessa proposta, tomamos de empréstimo a expressão cunhada por Zygmunt Bauman, que, em seu livro de 2001, define o momento atual do desenvolvimento humano como sendo a "modernidade líquida" ou "fluida", oposta por essa fluidez ao estágio anterior a "modernidade pesada". O teórico social parte da ideia presente em Marx de que os movimentos da modernidade esfacelariam as relações humanas em todos os seus níveis, liquefazendo para isso as sólidas instituições tradicionais, para, em um segundo momento, produzir novos alicerces sólidos. Estaríamos hoje, pois, vivendo uma exacerbação desse fenômeno (liquefação), a qual gera uma nova dialética em que a estrutura do sistema-sociedade se delineia como distante da realidade imediata do indivíduo, sendo assim intangível e inquestionável para esse que vê seu cotidiano e suas relações imersas em um emaranhado fluido e não-estruturado, o que resulta numa intensa fragmentação dessa realidade.

A metáfora de fluidez escolhida por Bauman pode ser, pois, emprestada para definir o tipo de romance que estamos analisando, não só por uma questão de temporalidade, mas pelo que propriamente essa metáfora nos diz. A fluidez é uma qualidade de líquidos e gases, devida ao fato de estes terem suas moléculas pouco aderentes entre si e que deslizam umas sobre as outras, essa qualidade implica em que forças internas ou externas aplicadas a um sistema líquido ou gasoso sejam rapidamente

\footnotetext{
4 “O acabamento do enunciado é de certo modo a alternância dos sujeitos falantes vista do interior; essa alternância ocorre precisamente porque o locutor disse (ou escreveu) tudo o que queria dizer num momento preciso e em condições precisas. Ao ouvir ou ao ler sentimos claramente o fim de um enunciado, como se ouvíssemos um “dixi” conclusivo do locutor.” (BAKHTIN, 1992: p. 299).
} 
internalizadas pelo conjunto, resultando em mudanças de posição, de velocidade, etc., de suas partículas.

Aprofundando essa metáfora, para explicar o porquê da escolha de terminologia feita aqui, propomos observar outra característica de fluidos, os tipos de movimentos que descrevem. Quando em baixa velocidade, os fluidos têm em si a formação de lâminas ou camadas que se deslocam umas sobre as outras, com maior ou menor velocidade dependendo de sua viscosidade (maior a viscosidade quanto mais fortes as ligações intermoleculares), esse movimento é dito escoamento laminar. Já quando em velocidades maiores os fluidos descrevem movimentos de turbilhonamento, onde as lâminas de fluido se desfazem e o deslocamento que ocorre se dá do fluido como um todo, mas também dentro do fluido entre uma molécula e outra. Quando pensamos no texto analisado, vemos que não existe um continuum na apresentação das informações que constroem o mundo proposto pela obra. É como se houvesse várias lâminas de história - todas compostas por uma mesma essência, e compondo um sistema - que escorrem umas sobre as outras deixando ver por vezes partes de uma em outra, escondendo, por outras, pela sobreposição, dobrando-se de forma dinâmica umas sobre as outras. Como veremos, o ritmo narrativo vai sendo acelerado de uma história para outra, partindo do que seria o movimento inicial de "Uma fábula" até chegar ao estágio de "O segredo". Mais uma vez tendo em perspectiva a dinâmica de fluidos, de que emprestamos a terminologia, podemos observar que à medida que a velocidade desses movimentos de narração aumenta essas lâminas se quebram em moléculas, ou seja, frações das histórias, que passam a interagir em um movimento dito agora escoamento rotacional e (ou) turbulento. Isso no texto seria representado pela intensificação do uso do recurso de fragmentação da escrita. Essa obra se apresenta, pois, de uma forma diferente do romance tradicional, ela se estrutura com base em diversas narrativas que se movimentam, ora distanciando-se, ora aproximando-se e formando novos significados. Esses movimentos narrativos dão a esse "romance fluido" um dinamismo que cresce de acordo com o tempo da realidade narrada: no começo lento, barroco, rural, e depois urbano, contemporâneo, desesperado.

O livro de Ruffato traz, como dissemos, uma série de citações que dão a direção de sua ficção. Com isso o autor além de demonstrar ser um grande leitor, dialoga com as outras obras de arte citadas e assim articula uma resposta contemporânea ao que foi criado anteriormente. Em uma primeira abordagem do livro, vemos sua capa, que contém o título: Inferno provisório volume I: Mamma, son tanto Felice. Esse título lança as bases do volume que leremos a seguir e da pentalogia como um todo. O título "Inferno provisório" é extraído do $29^{\circ}$ verso do poema "Novíssimo Job" de Murilo Mendes: "Prefiro o inferno definitivo à dúvida provisória". Ruffato seleciona e se apropria de duas palavras do verso citado para construir um sentido totalmente novo e diferente do inicial; o autor dessacraliza o conceito de inferno, que na tradição judaicocristã é perene, e atribui a ele a qualidade temporal e a impermanência, que são inerentes à vida terrena. Ele dá nome à macro-história que projeta contar sobre trabalhadores brasileiros, imigrantes italianos e descendentes de italianos e de como suas vidas se desenrolaram no contexto de modernização que ocorreu no Brasil, nos últimos cinquienta anos. Esses trabalhadores passam assim do contexto rural, para uma 
realidade de choque entre o rural e o urbano, até chegarem ao contexto urbano. $\mathrm{O}$ "nome", ou melhor, expressão escolhida por Ruffato, funciona, pois, como síntese dessa macro-história.

O subtítulo Mamma, son tanto Felice, por sua vez, foi extraído do primeiro verso da canção italiana "Mamma" de Cesare Andrea Bixio e Bruno Cherubini, de 1940, que se trata de uma alegre canção de exaltação do retorno ao seio materno, e que lamenta/critica a distancia anteriormente vivida. Na folha de rosto do livro o autor completa o verso na $3^{\mathrm{a}}$ epígrafe que escreve para sua obra: "Mamma, son tanto felice/Perché ritorno da te" ${ }^{, 5}$. Podemos então analisar esse título já como início da narrativa. Observamos, pois, que o imigrante é o indivíduo deslocado por excelência muitas vezes não consegue se comunicar pelo entrave da língua, não consegue fincar suas raízes em uma cultura diferente, não consegue ser igual - e tem sempre o sonho de retornar ao seio da terra natal - mãe. O imigrante, na maioria das vezes, não decide sair de seu lugar de origem por mera vontade, há forças externas que atuam nessa saída, que muitas vezes é na verdade uma fuga: de uma realidade política, da fome, da falta de condições para viver, entre outros. Ele parte para ter como retornar, assim o "inferno" da distância de sua terra, sua cultura, sua realidade, seria "provisório", tendo como felicidade o reencontro com a mãe/terra natal. A questão resta em saber se essa felicidade será concluída ou se fica na esperança do imigrante. Ao mesmo tempo, o título e o subtítulo constroem um paradoxo quando apenas justapostos: como estar feliz em um inferno, mesmo que seja provisório?

Observamos que "Mamma, son tanto felice/Perché ritorno da te" é a terceira epígrafe que ocorre antes do começo do livro propriamente dito. A primeira é uma citação bíblica que aparece como "Daniel 14:38", , que está no final do livro de Daniel, que compõe o antigo testamento, na parte intitulada "Episódio do dragão". Esse episódio narra o confronto de Daniel e seu rei que idolatrava um dragão; nele Daniel afirma só haver um Deus e com autorização do rei mata o dragão com uma mistura de gordura e pelos, mostrando que esse era simplesmente mais um falso ídolo. O rei se converte ao Judaísmo, mas acaba tendo que entregar Daniel aos outros adoradores, que enervados com a morte de seu ídolo jogam-no na cova dos leões. Daniel passa sete dias na cova sem que os leões o devorassem, por intercessão de Deus. O trecho citado é, pois o agradecimento de Daniel ao seu Deus. Mais uma vez há um teor de esperança muito forte, ao passo em que a tradição judaico-cristã é relembrada.

A segunda epígrafe é o trecho do poema épico "A invenção de Orfeu" de Jorge de Lima, que podemos interpretar como sendo mais uma alusão ao imigrado que parte, mas nunca chega, por não poder se adaptar à realidade em que chega, por trazer consigo os problemas de sua origem. No caso desta saga, podemos pensar que se trata de uma crítica às narrativas tradicionais que tratam de imigração, porque a imigração desses italianos fracassa, eles partem da Itália onde viviam em um estado de extrema pobreza para continuar na miséria no contexto brasileiro, sem qualquer possibilidade de retorno e sem qualquer possibilidade de permanecer de fato, tanto é que são eternos nômades, que partem de uma cidade para outra, sempre trabalhando.

\footnotetext{
5 "Mamãe, estou tão feliz porque retorno a teu encontro" tradução minha.

${ }^{6}$ Em consulta a uma bíblia católica vemos que se trata na verdade de Daniel 14:37.
} 
Essa viagem/fuga começa, como é possível presumir, saindo da Itália, em navios que rumavam ao continente americano. Já aqui no Brasil, a saga de Inferno provisório, tem seu ponto de partida na primeira história do livro: "Uma fábula". Esse título gera novamente uma expectativa, pois como fábula deveria oferecer uma moral. Porém, ela se mostra mais como um mito da gênesis dessa saga, o qual define a pedra fundamental, sem para tanto trazer uma moral. O teor mítico dessa primeira história se dá entre outros pela falta de marcações temporais precisas. Mas, sabemos que estamos em um meio rural, em um contexto pobre e onde não há infraestrutura. Leia-se o trecho:

“"tia' Maria Zoccoli suava ao alembrar: dos que chegaram pelas suas mãos e vingaram (...) embora doessem-lhe quantos inascidos!, abortos horrendos, monstros aleijados, anjinhos semeando o-lado-de-trás, o das bananeiras, das casas das fazendolas nos derredores de Rodeiro, quantos!” (RUFFATO, 2005: p.15)

Observamos a figura da parteira “"tia' Maria Zoccoli” e a alusão à grande mortalidade infantil, que nos remetam a uma realidade de pobreza. Além disso, somos situados na zona rural pela referência à cidade de Rodeiro (que nos acompanhará durante todo o livro, como veremos), interior da região de Ubá em Minas Gerais, e pelo uso da linguagem em "alembrar" ou "inascidos", que mimetiza a fala do interior.

Sabemos de antemão que a saga de Ruffato começa na segunda metade do séc. $\mathrm{XX}$, mas esse contexto que nos é apresentado poderia ter sido vivido em qualquer outro momento de nossa história, até mesmo nos dias atuais. Isso, porque a realidade rural se mantém a margem dos fenômenos sociais históricos, seguindo em um ritmo quase constante desde antes da revolução industrial. E isso faz com que o choque entre roça e cidade, que ocorre desde sempre, acentue-se com o passar dos anos e com a evolução (aqui não entendida como uma melhora, mas sim como um fenômeno observado ao longo de um determinado tempo) dos processos de modernização. O tempo do campo é lento, guiado pelos fenômenos naturais: o homem do campo não precisa de relógio este que é uma invenção da revolução industrial e servia para marcar o ponto dos operários - ele acorda quando nasce o sol, quando os outros bichos acordam, e se deita quando o dia já não apresenta mais luz. Outro fator de "lentidão", relativamente ao tempo da cidade, são as distâncias, enormes no contexto rural: uma casa fica muito distante da outra, o espaço de trabalho do camponês é vasto, sendo, que também o fruto de seu trabalho demora a aparecer, visto que sua lida é esperar o tempo de prepara a terra, plantar e só então colher. Para nos inserir nesse ritmo, nesse contexto, Ruffato se vale de uma linguagem escrita muito próxima à falada e estrutura seu texto de uma forma muito mais lenta, como se alguém nos contasse um causo, como se de certa forma estivéssemos ouvindo um rodeirense falando e contando-nos essa "fábula".

Nesta história, temos um homem, um adão, como organizador de sua realidade, um europeu que chega "industriando" (idem p.16) a terra, "uma imundície de jaguatiricas" (idem p.17), um trabalhador que usou seu sangue e seu suor na construção de seu paraíso, como lemos no trecho que se segue:

Estreou derribando árvores e alastrando fogo nos tocos, puxando água de uma mina com engenharia de bambus-gigantes, marretando pedras para soldar as bases do corpo central da casa seis-cômodos, as mãos febris de calos, os ombros empapados de sangue pisado. (...) E, presidiário de sua obsessão, comeu sete meses de sua vida na ampla solidão do paraíso. Labutando de em-antes do sol espantar a roncaria da madrugada até os dedos formigarem de sono, pois urgia o tempo (...) Quando deu 
por finda a faina convulsiva compareceu, fosse uma visão, na rua, socado dentro de um terno-gravata marinho mandado feitiar no Singulani, asas imensas nas senjeiteza dos modos, pés escalavrados no pelourinho da bota rinchando de nova, de casa em casa da "colônia" caçando a eva que iria povoar aquele mundo virgem de vozes. (idem pp. 16-17)

$\mathrm{Na}$ acepção mais próxima de "crescei e multiplicai-vos", este homem, "o Micheletto velho" (idem p.15) "solto no mundo, desmamado de pai e mãe" (idem p.16), como pecador original, dá início a seu legado. Assim como o Adão bíblico, que lança as bases do machismo (a mulher deve sua existência ao homem, que gentilmente cedeu uma costela para que ela fosse moldada) ou pelo menos trata de legitimá-las, a figura de nosso imigrante, viciado de tradição, lança as bases sobre as quais serão construídas as histórias que se seguirão, onde os papéis sociais são determinados aos moldes de uma sociedade patriarcal arcaica.

O texto põe em oposição o pai - gordo, forte e valente, que se impõe frente às dificuldade criadas pelo ambiente - e a mãe - fraca, imperfeita, inútil, que sucumbe ao cumprir sua função primeira de gerar herdeiros: "[Chiara] 'doente' todo ano, embarrigada, esvaindo a mocidade pelos baixios" (idem p.15).

Não só a figura do pai se sobrepõe à da mãe, mas de forma geral, a figura masculina é claramente dominante sobre a feminina. Podemos ver isso no fato de o sobrenome paterno ser maior que o indivíduo, sendo "Micheletto" soberano sobre a individualidade de "Chiara Bicio" (idem p.17), convertida em "Micheletta velha" (idem p.15). Onde pai é na verdade "Pai" (idem p. 17) com a importância maiúscula, em oposição à "eva" (idem p.17) diminuta. A mulher, na persona de Chiara Bicio, por seu silêncio e passividade faz ressoar toda a ausência de direitos e toda a impossibilidade que o jugo do patriarcalismo lhe impõe. Refém de sua condição, ela morre isolada em um cárcere privado, reificada e irreconhecível, como qualquer das outras "coisas" de seu Pai, senhor e marido. Isso pode ser lido no trecho que segue:

\footnotetext{
"a ampulheta da vida de Chiara Bicio, a Micheletta velha, inverteu-se: ela começou a morrer. E esgotou-se hora a hora, a saúde murchando na sangria estúpida de partos, e o juízo escapando por entre as fímbrias das úmidas árvores que uivavam nas noites intermináveis. De começo pensava, pelo menos a visitaria a família, mas desatinou, o Pai rompeu com os Bicio, assenhorando-se de que parente nenhum viria rondar coisas suas, algemando-a nos cordões umbilicais de gravidezes sem fim, largando-a desamparada, minguando num quarto de portas e janelas trameladas por fora, de onde saiu trinta e cinco anos rija, enrolada numa toalha-de-mesa, tão pássara que até o vento insistia em carinhá-la em sua derradeira viagem em carro de boi cantador até a igreja de São Sebastião, quando, para comparecer decente à missa de corpo presente, vestiram-na em madeira, gente havendo que desacreditava. É ela mesma!" (idem p. 21)
}

Essa dominância também é evidenciada pela figura de uma das filhas, que ao transgredir a regra social e manchar a honra dos "Micheletto", deitando-se com "um qualquer", é arrastada pela cidade e em seguida morta pelo próprio pai. Nesse trecho a mulher chega a ser questionada por uma autoridade, um "Seu doutor" (idem p. 19), que lhe pergunta: "Você é filha dele?" (idem p. 19). Mas, ela segue sua sina resignada, balançando "a cabeça positivamente" (idem p. 20), porque já nada poderia ser feito, ninguém poderia defendê-la, sendo ela posse daquele seu algoz. 
A identidade do pai na tradição ocidental patriarcal se constrói sempre em oposição aos demais - mulher e filhos, ele se define como repressor. Podemos ler a forma como isso se dá em relação aos filhos, mesmo sendo eles do sexo masculino, nas seguintes passagens:

"Os olhos de André iluminaram o Pai (...) quantos anos tinha então? dois? três? Quantos afagos ainda lhe faria aquele homem?, tão alto que temia fosse bater a cabeça nas nuvens, tão calado que assustava-se quando reboava a sua voz, tão esquisito que ao cruzá-lo nos calçamentos os conhecidos, garimpando os chãos, soltavam um muxoxo, que era um cumprimentar não cumprimentando, tão sistemático que o evitavam na estrada.” (idem pp. 17-18, grifo meu)

\section{$\mathrm{e}$}

“a mão árida do Pai assobiou seu rosto (...) E quantos outros roxos no corpo de André ainda desenhariam aquelas mãos? Uma birra, uma cisma, um desgoverno, um escorregão, uma chuva, um desando, uma febre, um sumiço, um descontrole, uma desinteligência, tudo dava nos nervos do Micheletto velho que, cego, usava o que estivesse à frente, acha, porrete, corrião, vara-de-marmelo, bambu, relho, chicote, cacumbu, até quando?, revoltava-se, até quando?" (idem p.22, grifo meu)

A identidade do filho, nesse contexto, tem um caráter muito díspar da identidade burguesa da criança: futuro da humanidade e como tal investimento lucrativo. Como no antigo ditado, usado na música de Walter Queiroz " "menino, cachorro e tamanco: tudo de baixo do banco", , a prole é tão grande, frágil, e insignificante, por não representar força de trabalho alguma, que não passam de "bichinhos" indistintos, sem face/personalidade, como é possível ler no seguinte trecho:

"E eram tantos os nomes, tantos os rostos e tão pouca a ciência, que renunciou [o Pai] a singularizar a fisionomia daqueles bichinhos que habitavam os corredores da casa. Quando necessitado, ordenava, 'filho, isso assim e assim', 'filha, isso assim e assado', e candeava suas afeições mais pelas criações e pela lavoura que pela prole, que aquelas dão trabalho, mas alegrias, e estas decepções apenas." (idem p.16)

Ao cabo desta narrativa a personagem de André, que passou por sua vida como um Cândido de Voltaire, sem se dar conta, almeja partir daquele contexto rural e ir para a cidade, conseguir subir na vida. Mas ele não parte, fica apenas na intenção, sem rumo reproduzindo os papéis sociais que lhe foram impostos. Já o patriarca, que seria senhor de tudo, finda sozinho, abandonado por amigos e parentes, e desiste de tudo para viver em seu paraíso particular, como se lê no trecho seguinte:

“o Pai, besteiro, concordando na diáspora dos sobrantes, dispersos aos quatro-cantos Michelettos e Bicios, sitiou-se na fazendola, homiziando-se entre os animais, comendo, bebendo e dormindo com eles, bicho-ele-mesmo" (idem p.23)

\footnotetext{
${ }^{7}$ Compositor baiano de canções como "Filho da Bahia" e "Pode entrar" conhecidas na voz de Fafá de Belém.

${ }^{8}$ Trecho da música "Tudo debaixo do banco" gravada no disco Filho do povo de 1977.
} 
Assim, temos a fábula/raiz a partir da qual todo o resto do livro e provavelmente da saga irá alimentar suas ramas até chegar à São São Paulo ${ }^{9}$ (título provisório do último livro da pentalogia ${ }^{10}$ ), cantada na música de Tom Zé.

O segundo momento dessa viagem é a história "Sulfato de morfina", que tem uma epígrafe sobre a morfina, que explica: quando nada mais analgesia, quando nada mais é possível ela é o último recurso. Diz-se que a única coisa irremediável é a morte e o único a fazer é esperá-la, e esse narcótico vem como um auxílio nessa espera. Temos, desde o título lançadas as cores do fim de Dona Paula (idem p.30): "o sol afundava por entre as meias-laranjas" (idem p.29). A narrativa anterior tendo contado dos últimos dias de Chiara Bicio, que morre em silêncio - não sabemos o que se passa dentro do "quarto de portas e janelas trameladas por fora" (idem p.21). Em "Sulfato de morfina" também participamos dos dias finais de uma mulher, nesta história uma lavadeira. Ainda existe o narrador que nos contou a outra história, mas o tom muda em relação ao anterior, o ritmo se dá em função da personagem: existe espaço para que a voz da mulher relate seus dias permeados por lembranças e pessoas que vêm visitá-la em seu leito de morte.

"Dona Paula", como descobriremos nas lembranças descritas na página 39 do livro, é irmã de "Chiara Bicio" da história anterior, sendo, pois, Paula Bicio. Ela, como mulher, também esteve à mercê dos homens de quem foi posse, primeiro do pai e depois do marido, mas, diferente da irmã migrou, como seus antepassados (de Rodeiro para Cataguases) e por isso teve uma vida diferente. Estamos aqui, uns 20 anos após a morte de "Chiara" (Paula tem "Cinquenta anos!"(idem p. 34)), em um contexto urbano, na cidade de "Cataguases" (idem p.33). Há marcações - "fogão-a-gás", "tuperwear", "o marido aportar da fábrica", "as crianças de volta da escola", "o capítulo da novela-dassete" (idem p.29), "televisão" (idem p.30) - que datam e situam o leitor nesse novo contexto. Assim como o lugar o tempo é outro, um pouco mais rápido e marcado, o que é traduzido textualmente pela mudança de velocidade da narração e pela própria estrutura física do texto que muda em função do que está sendo dito. Esse tempo é agora o do relógio que D. Paula ouve do sofá no qual espera pela morte: "auscultando o preguiçoso tique-taque que empurra a manhã contra a tarde contra a noite contra a madrugada, pinga-pingar vigoroso das horas" (idem p. 32). Mas, mesmo com a mudança de lugar e de ritmo, ainda persiste a miséria - "da casa minúscula, cortinas americano cru separando os cômodos" (idem p.29) - a falta de oportunidades e opções: afinal, ainda são trabalhadores as peças que movem essa história.

Outra diferença é que há questionamento durante todo o texto e este vem comparado ao passado, pela voz de Paula Bicio ouvimos a voz de Chiara que apenas aceita sua realidade: "Não é sina, minha cruz, só traria mais confusão" (idem p. 39). Diferentemente, da irmã Dona Paula diz: “mas, para quê?, para quem?". Porém, a personagem mesmo questionando, não pode fazer nada por sua condição física, e se

\footnotetext{
9 "São São Paulo" é uma música do compositor baiano Tom Zé, que ganhou o IV Festival Record de MPB de 1968, e foi gravada pela primeira vez no disco Tom Zé - Sony Music - Rozemblit 50010 edições mono e estéreo no mesmo ano de 1968.

${ }^{10}$ NB: Posteriormente soubemos pelo próprio autor Luiz Ruffato, que o título São São Paulo será usado para um livro de contos especificamente sobre a cidade, sendo que o título para o último volume da saga Inferno Provisório será Domingos sem Deus...
} 
observarmos mais atentamente, nunca poderia ter feito, por sua condição econômica. E isso fica claro na alegoria da morte que é a mesma "para todos, para todas..." (idem p.38) os/as iguais a ela: trabalhadores pobres. Há também a continuidade da tradição, que aumenta a impossibilidade de ter outro destino. Isso é sintetizado no seguinte trecho:

\begin{abstract}
"Família... casamento... filhos... uma insidiante epiderme de mofo impregna todas as histórias, esporos furtivamente carcomendo qualquer esperança... assim, nos primórdios... assim sempre... uma praga... uma maldição desembarcada do navio Carlos R. em Santos, camuflada na bagunça das tralhas recolhidas nos baús do Bicio, dos Furlaneto, cujo sangue cinco anos mais, se misturaria a ansiosa melancolia de Giacinto, a nostalgia embirrada de Elisa, ele vinte e dois, ela quinze anos. Corcoveando o mar-oceano pulgas, baratas, percevejos, ratos, eriçados frangos engaiolados, hirtos pescoços, proprietários do impossível retorno, ignorantes do daqui-a-pouco, no nunca-jamais, enterrados os ossos antepassados, soterrados os corpos, rasgadas as memórias do visto, saboreado, cheirado, pegado, ouvido, o Brenta, o paesello, as Dolomitas, a Basílica do Santo, martirizada a história em estrangeiras manhãs suarentas, sob a planta dos pés terras ordinárias, casebres escalando montanhas em perdidos sertões, saúvas, redescobrimentos. E exsurge, imenso o Inferno, não o do catecismo, labaredas fustigando condenados, tridentes sujigando pecadores, gritos de tardios arrependimentos, mas outro, encenado em certa casa, náufraga oculta trás um basto bambuzal" (idem pp. 39-40)
\end{abstract}

A obrigatoriedade de continuidade é um fado que a tradição da pobreza - herdada por azar - acomete essas pessoas, sendo que sem dinheiro, é quase impossível ascender socialmente. $\mathrm{O}$ trabalhador rural italiano, pobre expulso de seu país por essa pobreza e pela necessidade que ela gera, veio em navios imundos e chegou ao outro lado do atlântico para conquistar seu sonho e "fazer a América", aqui chegando, é exilado sobre um monte de terra em Minas Gerais e mesmo que trabalhe e arda sob o sol, não consegue sucesso. Sua descendência, aqui representada na figura de Dona Paula, vê-se novamente obrigada a desertar e partir para tentar ganhar a vida em outro lugar que lhe ofereça pelo menos a esperança de algo melhor. Porém mesmo em um contexto urbano a personagem passa por miséria igualável à de seus antepassados.

Da mesma forma que o passado - herdado - é questionado, essa nova realidade -conquistada - também é, pois ela confronta o exilado da roça a uma série de outras problemáticas - violência, caos, "fim-do-mundo" (idem, ibidem) - mas que, sobre tudo, gera mais um movimento de desenraizamento: o campesinato começa a se transformar em proletariado. E com isso as tradições são derretidas, o sangue dos Bicio é "sujo" (idem, p.35), contaminado, por essa nova realidade. E nossa personagem no último de sua vida reza em italiano para conseguir "ritornare":

"E catava à superfície orações que emergiam do lá da infância, frescas novamente, Padre nostro che sei nei celli, sia santificato il tuo nome... Credo in Dio, Padre onnipotente, creatore de cielo e della terra... e irrompia sôfrega na morte.

Ela resgata o mais primordial que lhe foi ensinado: a religião na infância, mas pedir um alívio ao sofrimento?, uma resposta? Acreditamos que seu último desejo é traduzido em uma afirmação que vem no final da história: "enterrado [o patriarca Bicio] no cemitério de Rodeiro, onde convivem os seus mortos e em breve também estará [Dona Paula]" (idem p.42). E o que podemos perguntar é se de fato será possível realizá-lo dada a 
pobreza e o descaso dos filhos de Dona Paula, assim ela é também uma "proprietária do impossível retorno".

O terceiro passo dessa jornada é "Aquário", sendo este um título bastante emblemático e simbólico, a partir do qual podemos levantar várias hipóteses sobre o que leremos, que poderão ou não ser confirmadas pelo texto subsequente. A primeira ideia que levantamos aqui é que dentro de um aquário existe um cenário que imita a realidade - pedras, plantas, imagens, água com a química adequada aos animais que dentro dele habitarão, etc. - e, até onde sabemos, os animais que vivem dentro dele não sabem de sua condição, não se dão conta de não estarem em um ambiente "real". Outra coisa que podemos levantar do conceito de "aquário" é sua função: um aquário é transparente para que possamos ver o que há nele. Num primeiro momento, podemos pensar numa função decorativa, em geral pessoas comuns criam bichos em aquários por sua beleza ou raridade; num segundo momento, podemos pensar na função de simulação do habitat real para o estudo dos espécimes, para promover o entendimento por parte de quem deseja estudar aquele/s animal/ais. Se pensarmos no trabalho de um escritor, podemos fazer um paralelo com o de quem monta um aquário, pois, o escritor simula o real com elementos dele próprio (imagens a partir de um código linguístico). Ele cria "egos experimentais" (KUNDERA, 1992) - personagens - e monta seu texto, observando-os, como o primeiro leitor e, em seguida, nós observamos pelo vidro simbólico que nos separa dessa realidade.

Na sequência, temos uma epígrafe que soa como um apelo ou pedido ao divino: "...soccorri quati sono provati dalla malattia, dalla sofrenza, dalla solitudine..." também lança as bases do que leremos. Aqui, podemos pensar sobre quem faz esse apelo, de fato é o escritor; mas, se imaginarmos que o ofício deste se dobra sobre ele mesmo e nos mostra as marcas de sua feitura, podemos imaginar que Ruffato dê mesmo voz aos bichinhos exóticos que vemos no aquário. Por outro lado, essa citação em italiano, traz consigo toda a tradição que embasa a vida das personagens que compõem o livro. É um apelo de um imigrante, ou de um seu descendente, para que a cadeia de males - doença, sofrimento, solidão - que acometem esses seres cesse.

Isto posto, observamos que na terceira história do livro continuamos no contexto urbano de Cataguases, mas o nível de pobreza parece ser menor, pois as personagens têm um carro e a possibilidade de viajar para a praia. Temos duas personagens, mãe Dona Nica - e filho - Carlos, que após a morte do marido e pai viajam para Guarapari. A história se passa de fato na estrada, mas o ponto de partida é a cidade, e são elas que pontuam os trechos/subdivisões do texto, bem como o horário no qual houve as paradas que dividem o texto. Assim, o fio condutor da história é um advento da modernidade: a estrada pavimentada, composta pelas BRs pelas quais as personagens passam até chegar ao seu destino.

O trajeto entre o ponto de partida e o de chegada de uma viagem é um momento em que não se pode fazer muito mais que pensar. Essa viagem, esse tempo ocioso, poderia ser, então, um mergulho nos pensamentos das personagens, pois mesmo conversando, estão continuamente pensando e um pensamento acaba puxando outro, assim num continuum. Os recursos estruturais da história anterior também são mantidos

11 “socorre todos aqueles que são provados pela doença, pelo sofrimento, pela solidão", tradução nossa. 
e acabam sendo mais explorados, havendo um padrão para mudanças tipográficas que seguem mais ou menos o seguinte esquema:

- narração do presente do texto: normal;

- pensamentos das personagens: itálico;

- lembranças das personagens que são a narração do passado do texto: entre parênteses.

Nesta história fica claro o dinamismo laminar do texto, pois, o ritmo é agora ditado pelo tempo psicológico das personagens que, ao viajar e ver a estrada e suas cenas pela janela do carro em que estão, vão puxando o fio da memória e trazem à tona lembranças e questões não resolvidas do passado comum e do pessoal. As lâminas de outras histórias vêm intercalando o itinerário principal. Nessa viagem há, na verdade, outras inseridas, há, na verdade, vários pontos de partida e de chegada.

Temos delineados os traços da família Finneto Silva (Finneto da mãe e Silva do Pai), o sobrenome italiano é uma retomada do sobrenome de "tio Antonio Finneto" que aparece na página 16 do livro, na história "Uma fábula". Assim, percebemos que de fato todas essas vidas estão interligadas, e que sua origem é a mesma. Silva é o sobrenome português, ou se preferirmos, brasileiro, que demonstra a mistura que ocorreu, dos italianos que aqui chegaram com os que aqui já estavam, esse fato destoa do hábito mostrado na primeira história do livro de ir buscar um cônjuge na "colônia" (idem p.17) e que faz com que a distância com a tradição italiana aumente.

Assim, temos a família constituída da mãe, do pai e dos filhos: "Éramos quatro, a ninhada. Fernando, o mais velho," Norma, Carlos e "Nélson, o mais novo (Ruffato, 2005: p. 46). A figura do pai mostra-se, a priori, diferente dos demais patriarcas que vimos, pois este tinha "orgulho: os filhos todos formados.", e lhes deu o que não pôde ter (idem ibidem). Mas, em seguida descobrimos que este pai, bem como o irmão de Carlos, Fernando, são, na verdade, moldados à imagem e semelhança de seus antepassados: machistas, bêbados, defensores de uma falsa moral. E aqui está o questionamento mais forte desta história, pois, Carlos, confronta o pai e rompe com a família, e o que deflagra esse movimento é mais um episódio de violência doméstica, em que o pai alcoolizado bate na mãe de Carlos, e este se mete para defendê-la e acaba batendo em seu pai. Carlos se exilou, assim como seus antepassados, mas o motivo foi outro: uma ruptura com o sistema patriarcal, com a tradição familiar. Ele se transformou em um náufrago solitário. Sobre este conflito de gerações Carlos pensa, em determinado trecho do livro:

Minha mãe nunca engoliu o fato de eu ter me rebelado contra meu pai, de ter evidenciado a sua ignorância, a sua hipocrisia, as suas mentiras, de ter desvelado o quanto todos éramos cúmplices de sua vida torta, de sua piedade de ocasião, de seu moralismo amorfo. Ela nunca me perdoou por ter rompido com a família, por ter escapulido da mediocridade, por ter me recusado a carregar o quinhão que me cabia naquele fardo. Queria que eu tivesse permanecido ali, sob suas asas, para sempre, como meus irmãos, comendo de sua mão, aninhados à sombra daquela tragédia que contaminava a todos." (idem p. 51)

A mãe, oriunda também de Rodeiro, imigrante como Dona Paula, defende e representa a tradição que Carlos contesta. Ela fala no nome dos Finneto como se fosse algo sagrado e o filho logo em seguida diz: "Nome? Que nome, mãe? Finneto? Silva? Desde quando nós temos nome, mãe?" (idem p.65). O que revela um movimento de 
dessacralização da instituição familiar. Em outro trecho ele afirma: "Uma família, eis tudo o que não fomos." Carlos mostra, analisando de forma bastante determinista, como, podres na raiz, não poderiam ser nada.

Durante a viagem, Carlos questiona se a mãe foi feliz, incomodada ela responde "Claro que fui feliz." (idem p. 50). Em seguida ela lhe faz a mesma pergunta, e ele responde: "Ser feliz? Do meu jeito... acho que sim..." (idem p. 52). Sabemos que a personagem principal do conto não conseguiu adaptar-se ao mundo longe das asas da mãe. Em outro trecho lemos: "almejava estar sozinho" (idem p. 57). Há na personagem central da história uma forte contradição, pois mesmo rompido com a família Carlos "gostava de velharias" (idem p. 53), tanto que é quem exige, da mãe, explicações do passado, é quem mais se lembra, mesmo renegando essa memória. Por exemplo, ao se lembrar da avó, que "não falava nada em português" (idem p.63) e que morreu silente, e questionar isso, a mãe respondendo:

\footnotetext{
“- Ela morreu. Depois que venderam o resto da fazenda, ela ficou pulando de casa em casa. Até com a gente ela passou um ano... Mas não conseguia conversar com ninguém. Ninguém mais sabia italiano. Os filhos não tinham paciência de puxar pela memória... Os netos remedavam ela... Passava tempos sem abrir a boca. Até que começou a secar, secar... Um dia acharam ela murchinha, de bruços, na cama..." (idem p. 64)
}

Fazendo isso, Carlos questiona a morte da tradição - a língua (leia-se cultura/tradição) morre quando o último falante morre. A avó não é de fato a última falante do italiano, mas para aquela família é a última representante da tradição ancestral. Esse questionamento revela o profundo desconcerto com o desenraizamento, com a perda de referenciais, sofridos pelo descendente de imigrantes. Essa contradição é observada pela própria personagem, como se lê no seguinte trecho: "Eu queria deslembrar minha história. Pensava desmanchar as paredes do meu passado e fundar meu presente sobre novos alicerces. Bobagem!" (idem p. 57).

Carlos casou, teve um filho e abandonou tudo por não ser o que, segundo ele, sua mulher e filho mereciam: "Mariana [a mulher] precisava ter a seu lado alguém que entendesse a vida como um empreendimento, não eu, que me surpreendia si em saber que meu coração ainda pulsava" (idem pp. 58-59). Nas narrativas tradicionais sobre imigrantes, eles necessariamente são grandes empreendedores, aqui, um descendente de imigrante demonstra claramente que não o é, que "ansiava apenas a consumação de seus dias sempre iguais" (idem p.58). Em outro trecho ele admite o porquê de ter abandonado a família que ele mesmo construiu (o segundo abandono, sendo o primeiro, o abandono à família de origem):

\footnotetext{
“- É que no fundo, no fundo... eu tinha medo, mãe... medo assim... de acabar... como a senhora e o pai... Eu não queira isso para mim, mãe... A Mariana... A Mariana não merecia isso..." (idem p.61)
}

Mesmo renegando um fado semelhante ao de seus pais, assim como sua mãe que teve um único grande amor, "Ângelo Chiesa" (idem p. 54), que não pôde viver, ele também. Após ser questionado por sua mãe, da razão pela qual fumava tanto, aparece uma explicação, em lindo trecho da narrativa, que fala do sentimento expresso por Carlos em relação a um amor platônico cujo final transcrevemos aqui: 


\author{
“ aquela a quem nunca sequer abracei \\ caminha comigo ao meu lado \\ murmura ainda em meu ouvido \\ miram meus olhos seus olhos negros \\ arde meu corpo no fogo desta ausência" (idem p.69)
}

Percebemos o fracasso de Carlos, que assim como a mãe, teve apenas um amor verdadeiro na vida, o qual nunca chega a ser concretizado.

Retomando a questão do cigarro, nessa narrativa, temos uma espécie de motivo ${ }^{12}$ que se repete com frequência - "Carlos acende um cigarro". uma marcação do tempo psicológico da personagem. Já do ponto de vista do significado, poderíamos talvez entender esse motivo como o indício de um lento ritual de morte - suicídio. Assim, como a Dona Paula da história anterior, que espera pelo fim, a personagem central desta história também. E mesmo chegando ao final desta viagem sabe que ainda haverá um extenso trajeto: "É uma noite longa... que parece não acabar nunca... nunca..." (idem p. 70). Esse chegar é um nunca chegar pelo motivo que nos deu Jorge de Lima, de quem Ruffato empresta, como vimos, uma das epígrafes do livro.

O seguinte caminho trilhado pelo autor é o de "A expiação", a quarta história do livro. Esta não vem precedida por epígrafe e está dividida em três partes que chamaremos de sub-histórias: "Ritual", "Fim" e "Tocaia". Entre as quais há mudanças muito semelhantes as que ocorrem de uma história para outra: mudança de velocidade barroca - a outra - dinâmica, bem como de cenário - de Rodeiro a São Paulo.

Avaliando a estrutura do livro, podemos perceber que o todo - livro/macrohistória - aparece sintetizado mais ou menos na sua metade, na quarta sub-história. Essa retomada condensa os significados propostos e propicia ao leitor reavaliar a história como um todo ${ }^{13}$ do ponto de vista do entendimento da obra mas também do entendimento do fazer literário. Sendo possível usar novamente a metáfora de liquidez, onde a matéria - história/fazer literário - se dobra e redobra sobre si mesma deixando ver as marcas de sua feitura. Esse recurso de retomada também pode ser aproximado aos recursos usados na música. Por exemplo, na "Sonata", obra musical dividida em três movimentos, onde o segundo (metade da obra), geralmente lento, encontra-se em três partes (forma ternária), remetendo então à macro-estrutura da peça.

Tratando agora das sub-histórias propriamente ditas, a primeira, "Ritual", parte do enfoque em uma personagem: "O menino" (idem p. 75) (que só será nomeado duas páginas a diante como Zé Spinelli). Usando um recurso narrativo que podemos associar com um movimento de câmera ("close" abrindo para um "take" mais amplo), Ruffato

\footnotetext{
${ }^{12}$ Nos referimos aqui a motivo na acepção de Leitmotiv - em alemão, motivo de ligação ou motivo condutor - para definir o recurso usado, como veremos, em vários trechos do livro. A respeito da repetição de partes semelhantes ou iguais, podemos ler no livro Forma e estrutura da música de Roy Bennet o seguinte trecho que explica esse recurso aplicado à música:

É necessária alguma repetição das ideias musicais para dar certa unidade à peça - para melhor articular a composição. Algumas melodias podem ser ouvidas duas vezes ou até mais, durante a mesma peça. Essas repetições devem ser encaradas como pontos de referência, que servem para orientar-nos durante a peça. (BENNETT, 1986, p. 9)

${ }^{13}$ Recurso estrutural semelhante foi observado pela Prof. Dra. Elizabeth Hazin em seu artigo "A terceira travessia - uma leitura de Grande Sertão: Veredas".
} 
descreve o que o menino vê e suas ações imediatas de forma fragmentária, para assim construir um todo que o cerca: a história em si. Assim como o leitor, o menino não sabe o que está acontecendo e vai juntando os fatos para entender sua própria história.

Voltamos ao contexto rural de Rodeiro, que aqui aparece como um eco da primeira história. Além da retomada da cidade e seus lugares (jardim, loja do Turco, etc.), há a retomada das personagens que compõem o universo da pequena cidade, como: "Pivatto" da venda que aparece na página 17 em "Uma fábula" e depois na página 78 em "A expiação", e "tio Antonio Finetto", nas páginas16 e 77 do livro. Assim, somos novamente levados ao ritmo quase barroco da roça de dia e noite, de vida e morte, e confrontados com a estrutura social patriarcal que dita a forma de vida das personagens.

O título dessa sub-história se justifica pelo que acaba sendo revelado ao menino: a morte de seu pai, orlando Spinelli. Trata-se de um "Ritual" de morte, onde o que morre vira santo e todos seus pecados são apagados. Nele temos a despedida: "vai ver seu pai pela última vez" (idem, p.77); além de todos os outros símbolos católicos também herdados da tradição italiana: "dobre de sinos", "membros da Congregação Coração de Jesus", "flores", "coroas", e "os irmãos de seu pai apareceram conduzindo nos ombros o caixão" (Idem, p. 81). Nesse ritual o papel social das personagens acaba ficando mais claramente marcado, em função da situação extrema por que passam. A dicotomia homem mulher é reforçada, como podemos ler no trecho: "Já estava acostumado com os achaques da mãe e as aprontações do pai." (idem, p. 76); onde o menino percebe como se constrói a sociedade que o cerca.

Também temos a ideia do pai tradicional apartado dos filhos, vemos que Zé tem dificuldade de chorar seu pai, é incapaz de lembrar-se de algo de que realmente sentirá falta nele. Em paralelo, temos a questão fraternal que leva Zé a sentir muito mais por Badeco, seu irmão negro de criação, mesmo sendo ele acusado de matar seu pai.

Ao mesmo tempo em que temos o ritual de morte, temos também o ritual de passagem, que igualmente define as posições sociais dos indivíduos. Esse ritual é o que força o menino a se tornar homem. Com a morte do pai, de um dia para o outro, Zé tem de tomar as rédeas de seu mundo, sendo o homem da casa, porém, não é ele que decide isso, nem que decide como conduzirá sua vida, e sim o círculo familiar e social.

No trecho: "Assistiu a tudo calado, mergulhado na responsabilidade de seus treze anos" (idem ibidem); lemos a construção de um personagem com papéis a princípio contraditórios. Sendo ele criança, dentro de um contexto tradicional, não tem voz (como dito anteriormente), mas por ser o filho varão mais velho acaba por assumir toda uma carga de obrigações. Ele não tem poder sobre sua própria vida e apenas vive para cumprir com o que lhe é imposto pela sociedade. Isso pode ser visto no que dizem as pessoas que o vêm passar perto do velório de seu pai:

"Que tragédia, meu Deus! Que, Tadinho, tão novo, tão. É, aquele. O mais pequeno. E agora?, o que vai ser da. Graças a Deus a Assunta tem um filho-homem pra cuidar da. (...) O que vai ser desse menino, minha Nossa Senhora, o quê? Benzadeus, é forte como o pai! Aquele ali, ó. Alá ele.

Nesse ritual um dos símbolos de masculinidade é o álcool. A primeira coisa que a família faz com o menino é dar-lhe bebida, para dar-lhe coragem e força. Dizem: "Bebe, Zé, vai fazer bem procê, bebe." (Idem, p. 79) e assim ele se torna homem, dando 
os mesmos goles que os demais homens dão para ganhar coragem, o álcool sendo uma verdadeira necessidade: "vocês estão precisados" (Idem, p. 88)

Pulando para a terceira sub-história, "Tocaia", descobrimos que Badeco não matou o seu padrinho como todos pensaram. Ele acabou sendo condenado a viver uma miséria também, como se pode ler retomando a segunda sub-história - "Fim". Esta trata mais uma vez de uma história de morte: Badeco, aqui nomeado como Jair, nos mostra seus últimos pensamentos e lembranças como a Dona Paula de "Sulfato de morfina".

Vemos que ele é condenado pela própria condição: como cria da casa dos Spinelli em certos momentos é tratado como aparentemente um igual, um "Spinelli preto" (Idem, p. 80), mas que para o padrinho não passa de um bicho de sua posse, que ele pode açoitar e humilhar. Como negro e pertencente a uma classe social pobre, ele compartilha das mesmas impossibilidades enfrentadas pelos descendentes dos migrantes italianos. Como uma maldição contagiosa ele acaba sendo herdeiro de um destino de fracasso que acomete todos os personagens deste livro. Jair teve de fugir e de se exilar em um contexto ainda mais urbanizado: "São Paulo" (Idem p. 96) capital. E lá é marginalizado no centro, então, por estar perto do maior poder econômico, percebe de forma mais intensa a discrepância entre a sua condição miserável e o que o cerca. É ele quem sofre na pele o "fim-do-mundo" anunciado por Dona Paula. É na violência das drogas e vícios que seus filhos morrem e sua mulher enlouquece, deixando-o só. Só como o primeiro patriarca que aparece no livro, o Michelleto velho, mas por motivos diferentes, sendo aquele vítima de sua condição social, e penalizado sem ter culpa.

A desesperança é o que assola este personagem nos seus últimos dias, como se pode ler em: "Pastor, essa dor... até Deus não é amos... É vingança... é punição." (Idem, p.98). Jair é forçado a desempenhar um papel igualmente árduo como o de seu irmão de criação, ao estar só "ele a tudo agüentando, porque era homem, e um homem tem que agüentar" (Idem p. 99). Assim, ele também se sente culpado, pois no fim não agüenta e chega a maldizer e abdicar do Deus que deveria temer por tradição. Ele morre sofrendo como as mulheres que vimos morrer anteriormente, sendo possível, pois, traçar um paralelo com a condição de minoria do negro e da mulher. Porém, há uma diferença sutil que podemos apreender da comparação de dois trechos: como vimos previamente, que em "Uma fábula" onde a mulher é arrastada pela cidade amarrada, aqui também, o negro de criação o é, entretanto a autoridade policial pôde intervir e o episódio de repressão teve fim.

Na quinta história, "O alemão e a puria", temos a personagem Donato Spinelli, primo de Zé, personagem central da história anterior, que tendo aparecido anteriormente apenas como coadjuvante, agora figura como o alemão que aparece no título. Ele sai de Rodeiro, como gostaria de tê-lo feito o Andrezim de "A fábula", e passa a trabalhar como operário numa fábrica de Cataguases. Mas, mesmo tendo partido e trabalhado duro, Donato não consegue ser feliz, e vê frustrada sua esperança de melhorar. Ele constitui um casamento com uma descendente de indígenas - Dusanjos - e com ela teve um filho - José Batista - sendo isso um índice de miscigenação. Donato é um homem diferente dos outros que apareceram até então, é sua mulher que dirige a casa, que faz os acordos de compra e venda, e ele mostra então que não saiu da posição de coadjuvante.

Num primeiro momento da história temos a impressão de que ele se suicidara, jogando-se de uma ponte, mas, posteriormente, verificamos que, na verdade, Donato vai 
embora, deixando para trás mulher e filho. Com o sumiço do marido Dusanjos vê-se dilacerada pela dor do abandono e se apega à religiosidade. Ela passa da Igreja Católica, que não pôde consolá-la, ao "Centro Espírita Bezerra de Menezes" (Idem, p. 118), onde recebe a mensagem psicografada que lhe explica que essa dor é sua missão e que, portanto deveria resignar-se. Não tendo, porém resposta de onde seu marido estava ela vai a um centro de Umbanda (Idem, p. 120), lá a mãe de santo lhe diz: "quando você não se lembrar mais disso, as coisas mudam [...] o que a gente quer é o que acontece" (idem, p. 121). Em seguida, ela se torna protestante, sendo membro da congregação cristã "Cruzada Evangélica" (Idem, Ibidem), onde lhe dizem que "Debaixo do céu há momento para tudo e tempo certo para cada coisa." (Idem, p.122). As predições acabam por se completar ao dizer a mulher exatamente o que ela queria ouvir.

Dusanjos se conforma e segue sua vida cuidando de José Batista. Contudo, o marido retorna, da mesma forma como partiu, sem nenhuma palavra. A predição a princípio falsa da mãe de santo acaba se concretizando: ela esquece o passado e as coisas mudam. Há uma ironia na construção desse trecho muito semelhante com a presente em A hora da estrela, de Clarice Lispector. Neste a cigana anuncia a estrela a Macabéa, e ao cabo da narrativa descobrimos que esse seria seu trágico fim, naquele, a bruxa repudiada pela protagonista acaba sendo quem mais se aproximaria de uma verdadeira predição e não a bíblia cristã.

Esta história não é muito significativa em termos de extensão, mas, do ponto de vista estrutural da narrativa, ela tem função de aprofundar o uso de recursos de construção textual e da fragmentação que caracterizam a fluidez do livro, além constituir, juntamente com "Aquário" um segundo estágio de radicação no contexto da imigração, visto que aparecem filhos de migrantes constituindo famílias. Esse estágio vem imbuído de uma série de contradições entre a origem e o que se lhes apresenta no contexto social. Dentre eles, por exemplo, o surgimento e desenvolvimento de outros credos que vão de encontro à tradição e representam o abrasileiramento propriamente dito dos Spinelli - "uma alemãozada danada, cara-de-um-focinho-do-outro." (Idem, p. 113) - pela miscigenação com pessoas de outras etnias e por sua imersão em uma cultura outra que a deles.

O sexto momento da viagem proposta por Ruffato é a narrativa de outra vida e de seu fim, sendo a personagem central um homem, oriundo de Rodeiro, o "Chico" (idem, p. 141), criança da roça, levado por um tio para se tornar padre, mas não logra sê-lo, acaba se radicando em Cataguases e que se torna "o Professor" (idem, p. 125). A vida relatada nessas páginas é a de uma pessoa de uma classe diferente, pelo status de sua profissão e pelo poder econômico que ela lhe proporciona, porém a miséria psicológica é a mesma da dos outros personagens. Estes que aparecem nas lembranças do professor, o que no enfoque da narrativa pode ser entendido como uma recapitulação das outras histórias:

"E lembra de sua infância... À beira do caminho, as choças iam ficando para trás, ali morava o Orlando Spinelli; lá a fazenda dos Bicios; acolá, os Finneto; na virada do morro, os pastos Benvenutti..." (idem, p. 140)

Revemos, pois, os sobrenomes que permearam o livro até este ponto, dessa forma, o autor promove uma junção de todos os fios narrativos que teceram as cinco 
histórias anteriores com o nó de "O segredo", numa espécie de fechamento eidético. Todos, então, estão ligados de alguma maneira, talvez por terem o mesmo lugar de exílio, por elos de parentesco, casamentos, por serem todos italianos, mas, sobretudo, i/migrantes que vieram habitar esses lados das Minas Gerais. São seres que compartilham o nada - o mesmo destino de pobreza, o mesmo desenraizamento - e que na ausência do sentimento de pertença acabam por encontrar seus pares neste "Inferno provisório".

Há também um forte paralelismo com as histórias, como por exemplo, no IV e no VI trechos ocorre a retomada da pergunta feita, em "Aquário" por Carlos a sua mãe: "você foi feliz?" (idem, p. 50). Em "O segredo" o professor assim também é questionado, e responde:

\footnotetext{
“Aquela vidinha insossa... E no entanto, éramos felizes! Sim, felizes, porque a felicidade é a ignorância... O homem que não conhece, esse é o homem feliz." (Idem, pp. 134-135)

"Éramos tão inocentes... Tão ignorantes... Tão... felizes... Ah!, os tempos felizes da minha miséria." (Idem, p. 136)

"E, quanto mais conhecia, mais infeliz me tornava..."
}

Mesmo sendo ele um homem, tendo fugido do papel que lhe impuseram, Francisco fracassa. Dessa maneira, é colocada em cheque a farsa igualmente vivida por Dona Nica e por nosso professor.

A história de "O segredo" é dividida em partes numeradas, as quais trazem o estilo fragmentar de Eles eram muitos cavalos, livro que consagrou Luiz Ruffato. Nessa fragmentação a narrativa vai se desenrolando em um movimento de turbilhonamento, que é ditado por um ritmado fluxo de consciência. Este é organizado e pontuado por trechos que se repetem como, por exemplo: "poltrona camurça verde descolorida, estrategicamente pousada num canto da sala, entre a janela e o móvel da eletrola" (idem, p. 125); "mira-se no espelho, arruma o nó da gravata, compõe melhor o paletó, passa os dedos longos e secos pelo cabelo grisalho" (idem, p. 126); "E passou a língua nos incisivos" (idem p. 137); entre outros. Esses trechos aparecem em momentos diferentes exatamente iguais, em outros, parcialmente reproduzidos ou levemente modificados, a narrativa modulando-se em motivos como se num tecido musical. $\mathrm{O}$ uso desse recurso dita um movimento espiralar à história, que vai se afunilando, e também lhe promove uma unidade pela repetição. Podemos observar que o ritmo dessa história é a acentuação e intensificação dos ritmos das outras histórias.

A ideia da morte presente em todas as histórias aparece aqui também de forma idealizada, como a única escapatória, sendo este um tema central. E o panorama é de decadência, como o próprio personagem diz: "a minha vida... só consigo ver ruínas à minha volta ... Ruínas... Apenas ruínas." O professor imagina como será o dia de sua morte e planeja o seu funeral, e sua maior dúvida é ao som de que música dar-se-ia: a Chacona da Partita $n^{\circ} 2$ de Bach, ou a Abertura de Egmont de Beethoven. Assim, durante toda a história lemos o motivo "Bach ou Beethoven?" que reforça a ligação com a ideia da musica.

Esse motivo é o principal objeto da história, e é a ele que nos ateremos agora. A primeira música é uma peça barroca para instrumento solo, que apresenta um tema em 
tonalidade menor, bastante solene e dramática, sendo um tanto marcial, a partir do qual são elaboradas inúmeras variações, onde há uma exploração quase experimental dos motivos harmônicos e melódicos, sendo extremamente longa (chegando a quase dezessete minutos). A segunda é uma abertura de um concerto para grande orquestra, do período clássico, que como abertura tem uma estrutura livre que pode se apresentar como um tema com variações ou como exploração motívica, ou mesmo como um prelúdio. Essa abertura começa de forma igualmente solene, porém mais triunfal, tendo variações de dinâmica mais contrastantes e com a intenção de demonstrar toda a potência orquestral. É hilário pensar em uma abertura para trilha sonora de um enterro, que na verdade é o fechamento, o fim de uma vida, e neste contexto também o fim do I volume da saga. Devemos observar que ambas as peças começam com motivos bastante semelhantes, sendo o tratamento dado pelos seus respectivos autores totalmente diferente.

A resposta à questão "Bach ou Beethoven?" é dada pelo fato de a peça barroca ser a última a ser ouvida pela personagem. Sendo que também devemos observar que a estrutura de tema com variações da obra de Bach é mimetizada por Ruffato na construção de sua história. Assim, a vida desse sujeito se resume à repetição de um mesmo tema - a culpa pelo fracasso - com variações de em que ele fracassa (em sua família como filho do meio, no seminário, como professor, como colaborador de jornal, como homem com relação às mulheres, etc.). E isso fica claro no devaneio que o professor tem de seu julgamento onde se lê:

\begin{abstract}
"Eu acuso o réu de alta traição. (...) Traição à família. Tripla traição à família, posto que traiu seus pais, pessoas humildes, mas honradas, abandonando-os numa difícil situação financeira para viver confortavelmente em um seminário católico, sem as preocupações comezinhas do dia-a-dia; traiu seus irmãos, ignorante se tornou do destino daqueles em cujas veias corre seu próprio sangue; e finalmente traiu a Nação, ao se recusar terminantemente a constituir família, célula-mater e sustentáculo da sociedade. Por tudo isso, Meritíssimo, peço para o réu a pena máxima." (Idem, p. 150)
\end{abstract}

Vemos que seu principal fracasso foi com a "Nação" italiana, foi com os que partiram da Europa e enfrentaram o mar para que seu descendente nada conseguisse. A esse respeito ele diz:

“sou um homem só... Um homem só no mundo... Perdi minhas antigas referências, o sótio, meus pais, meus irmãos, a paisagem da minha infância... E não acrescentei nada a isso... O que resta do meu passado? Ruínas... Apenas ruínas...” (Idem, p. 162)

Ele confirma o fracasso da empreitada. O homem migrante encontrou no Brasil um solo fértil para a roça, mas infértil para o seu crescimento. Estéril de esperança se tornou seco e suas raízes soltas acabaram por perder-se, ele, o migrante, se perdeu de si mesmo ao abandonar sua terra mãe e nunca mais poderá encontrar-se.

Podemos em última análise, observar que a obra como um todo pode ser ela também interpretada como a sucessão de variações sobre um mesmo tema. Em sendo a morte o único destino de tudo o que lemos, é a única possibilidade de "ritornare" - a paz de um fim. Temos nesse livro a morte como grande agente e, Rodeiro como grande narrador. A cidade de Rodeiro vê os que por ela passaram em momentos de nascimento 
e morte, mas principalmente de partidas é que se constituíram essas vidas. Essa cidade é o ponto de origem compartilhado pelas famílias e pessoas que aparecem nas histórias, é de onde partem os fios do tecido narrativo. E seus sobrenomes são unidos no lugar da memória, que é acima de tudo a memória do desterro, pois, mesmo compartilhando de um ponto de origem essas personagens não pertencem àquele lugar, nem a lugar nenhum, são eternos migrantes. Destarte, observamos que diferentemente das narrativas tradicionais sobre a vida de imigrantes, as quais constroem, para estes, uma identidade próxima à de herois conquistadores, a obra em questão retrata outra visão, muito mais crua e dessacralizada, sobre a imigração. O imigrante de Ruffato é um ser, que expulso por motivos econômicos de seu lugar de origem, parte em busca da promessa de "fazer a América" (FAUSTO, 1999) e acaba encalhando em uma realidade de nunca conseguir chegar, de nunca pertencer a lugar nenhum, e assim de repetir os mesmos passos nômades sempre procurando algo melhor.

\section{Referências Bibliográficas}

BAKHTIN, Mikhail M. Estética da criação verbal. São Paulo: Martins Fontes, 1992.

BAUMAN, Zigmunt. Modernidade Líquida. Rio de Janeiro: Jorge Zahar Ed., 2001.

BENNETT, Roy. Forma e estrutura na música. Rio de Janeiro: Jorge Zahar Ed., 1986.

FAUSTO, Boris. Fazer a América - A Imigraçao Em Massa Para A America Latina. São Paulo: Edusp, 1999.

RUFFATO, Luiz. Inferno provisório volume I: Mamma, son tanto felice. São Paulo: Editora Record, 2005.

\section{Bibliografia complementar}

BACH, Johann Sebastian. "Chacona da Partita no. 2 para Violino Solo, em Ré menor." In CD. Bach: Violin Concertos; Chaconne. Interprete Yehudi Menuhin Londres: EMI Classics, s/ data.

BEETHOVEN, Ludwig Van. "Abertura de Egmont" In CD Abertura Egmont / Sinfonias $n^{o}$ s 2 e 8 Interpretadas por Osesp-orquestra Sinfônica Do Estado De São Paulo São Paulo: Biscoito Fino, 2008.

BÍBLIA. Português. Bíblia sagrada. Tradução de Padre Antônio Pereira de Figueredo. Rio de Janeiro: Encyclopaedia Britannica, 1980. Edição Ecumênica.

BIXIO, Cesare Andrea e CHERUBINI, Bruno "Mamma" in CD Firenze Sogna intérprete Fernando Orlandis -

HAZIN, Elizabeth. "A terceira travessia - uma leitura de Grande Sertão Veredas" in (Pré) Publication - Forswing og undervisning $\mathrm{n}^{\circ} 144$ août 1994. Aarhus: Aarhus Universitet, PP. 22-49 
MARTINS, Antônio José Santana. Tom Zé Rio de Janeiro:Sony Music / Rozemblit 50010 - edições mono e estéreo: 1968

MENDES, Murilo. "Novíssimo Job" in O Menino Experimental. São Paulo: Summus, 1979.

http://w3.ualg.pt/ jargain/notasmecfluidfi.pdf, consultado em 22/03/2009 às 21h24.

QUEIROZ, Walter. Filho do povo São Paulo: Philips, 1977 